\title{
NONLINEAR RELATIONSHIP BETWEEN HOUSING SUPPLY AND HOUSE PRICE IN MALAYSIA
}

\author{
Geok Peng YEAP (D), Hooi Hooi LEAN (1)* \\ Economics Program, School of Social Sciences, Universiti Sains Malaysia, 11800 USM, Penang, Malaysia
}

Received 30 December 2018; accepted 19 January 2020

\begin{abstract}
The novelty of this paper is to ascertain a nonlinear relationship between housing supply and house price. This study is conducted based on panel dataset of four different types of houses in Malaysia from 2002Q3 through $2016 \mathrm{Q} 4$. Although housing supply has been theoretically assumed to be positively and linearly related to house price, we observed that the number of new houses build in Malaysia has declined despite the increasing house prices. Hence, we posit that housing supply and house price are nonlinearly related. The results from pooled mean group estimation show the existence of inverted U-shaped housing supply curve. The threshold level of house price index is found at 186.92 where the effect of house price on housing starts will become negative after this point. We also find that the marginal effects of house price evaluated at the minimum and maximum levels are positive and negative, respectively, and statistically significant. This paper suggests that the squared term of house price should be included in estimating housing supply in Malaysia. The evidence of inverted U-shaped housing supply curve in Malaysia shows that housing authorities have taken steps to overcome the challenges of oversupply by reducing the approvals for housing development projects.
\end{abstract}

Keywords: housing supply, house price, pooled mean group, nonlinear, Malaysia.

Supplementary material associated with this article can be found, in the online version, at https://doi.org/10.3846/ijspm.2020.12343

\section{Introduction}

Housing development is a critical determinant of economic growth of a country (Lee \& Jin, 2011; Alkay et al., 2018). However, a decreased trend of housing supply has been evidenced despite a growth of house price. For instance, in Malaysia, the number of housing starts has fallen from a high of 188,757 units in 2015 to 121,326 units in 2016, a drop of $35.7 \%$. The high-rise housing starts have dropped the most by over half from its peak of 109,057 units to 47,855 units during this period ${ }^{1}$. Over 2015-2016, Malaysian house prices measured by house price index have increased by $6.9 \%$ while the high-rise dwellings have the highest price appreciation with an increase of $8.4 \% 2$.

The above observation contradicts with economic theory that predicts housing supply should be positively related to house price. For property developers, a rising house price is a positive indicator of housing supply.

\footnotetext{
1 Refer to Quarterly Property Stock Report published by Valuation and Property Services (JPPH) of Malaysia.

2 Refer to Malaysian house price index data published by JPPH of Malaysia.
}

More houses will be built for sale when housing market is booming (Tse et al., 1999). Since housing supply is perfectly inelastic in the short-run, all increases in supply come from new construction (i.e. housing starts) (Barot \& Yang, 2002). However, Stevenson and Young (2014) argued that inelastic supply of housing in the short-run could cause the increases in house prices when the increased demand is translated into price behaviour rather than supply of more housing units.

Many empirical studies have demonstrated a positive relationship between house price and new housing supply (e.g. Poterba, 1984; DiPasquale \& Wheaton, 1994; Meen, 2005; Neto, 2005; Ball et al., 2010). However, Ooi and Le (2012) noted that house price and new housing supply could react negatively in the primary market. A recent study in Al-Masum and Lee (2019) reported housing supply to be one of the key determinants of house prices although it is weakly correlated with house prices. As such, there are two opposite conclusions regarding the relation between new housing supply and house price. A more recent concern has been whether higher level of house prices depresses new housing supply, for instance, Pryce (1999) has found a backward-bending supply curve

*Corresponding author. E-mails: hooilean@usm.my; learnmy@gmail.com 
during booms. Perhaps, there appears a weak relationship between housing supply and house price when these two variables are linked linearly. This could be attributed to the ignorance of non-linear component between housing supply and house prices.

In view of the above discussions, we argue that house price and new housing supply interact in a nonlinear manner. Particularly, we aim to investigate whether there exists inverted U-shaped housing supply curve. Following this model, we expect new housing supply increases up to an optimum level of house price before declining. The rationale of the nonlinear relationship between house price and housing supply could be explained as follows:

1) Uncertainty about future events contribute to a negative relationship between price and quantity of housing supplied (Pryce, 1999). Since housing developers predict future prices based on past prices, the number of housing starts will be negatively related to current house prices when future prices is expected to fall.

2) Regulations and development control imposed by the planning authority can contribute to the risk of housing development and influence housing supply (Mayo \& Sheppard, 2001). Regulations that induce delays to the development process will increase the value of vacant land but decrease the supply of housing in the current period. Mayer and Somerville (2000b) found that housing starts depressed by $45 \%$ in cities with extensive regulations.

Understanding how new housing supply response to house price is relevant because new housing supply is crucial in the economic growth of a country and a key element in wealth creation (Taltavull de La Paz \& Gabrielle, 2015). During an upturn of economic cycle, new housing demand pushes up house prices and thus increasing new housing supply. On the other hand, when housing demand falls, the existing housing supply either is met or exceeds the current housing demand (Taltavull de La Paz \& Gabrielle, 2015). Although house prices do not fall dramatically, there is less incentive for developers to start new projects and thus decreasing new housing supply. As documented by Stevenson and Young (2014), the disequilibrium in supply is responded slowly by developers whereas the disequilibrium in demand does not affect supply. Such observation provides an asymmetric response of new housing supply to house prices, with positive price elasticity during economic expansion and negative supply elasticity during economic contraction. This provides a basic for the hypothesis that new housing supply curve is inverted U-shaped with response to house price.

We examine the existence of inverted U-shaped housing supply curve in the context of Malaysian market. The Malaysian housing market provides an ideal case study in which its housing market has witnessed a rapid and sustained house price appreciation during 2010-2012 with an annual average increase of $9.1 \%$ as measured by Malaysian
House Price Index (BNM, 2012). Following house price appreciation and a declining trend of overhang and unsold properties in 2012Q1, housing approvals for construction rose substantially by $75.6 \%$ but housing starts declined by $1.1 \%$ due to cautious development sentiments (Valuation and Property Services Department [JPPH], 2012). Housing starts only recorded a sharp increase of $38.1 \%$ with 100,712 units in 2015Q1 contributed by significant increase in high-rise houses. This has subsequently led to increase in overhang by $30.7 \%$ and reduction in housing starts by 40\% in 2016Q1. Tan (2010, 2011 and 2012; TeckHong, 2011), Lee (2014) and Rangel et al. (2019) discussed the issue of properties overhang is critical in Malaysian housing market especially for low-priced and high-priced properties. Housing overhang has resulted in a freezing of housing approvals especially in service apartment and luxury condominium priced above RM1 million (JPPH, 2017). Perhaps, this unique feature of Malaysian housing market implies an increasing new housing supply when house prices going up; and a stagnant/reduction of new housing supply with a slow growth of house prices due to an increase in housing overhang. Therefore, Malaysian housing market appears as an interesting case to examine the existence of inverted U-shaped housing supply curve, i.e. an increase in house price increases housing supply until a threshold level after which an increase in house price decreases housing supply.

The first contribution of this study is to examine the existence of nonlinear i.e. inverted $\mathrm{U}$-shaped housing supply curve. While existing empirical studies linearly regresses housing starts on house price and other variables, we aim to demonstrate that there are good evidence for believing that the new housing supply will not increase infinitely in relation with house price but it will decline when house price increases above a threshold level. We discover the threshold level of house price. When house price increases above the threshold level, the effect of house price on housing supply turns negative.

The second contribution is to calculate the marginal effects of house price on housing supply at different levels. The marginal effects of house price on housing supply tell us the price elasticity of housing supply varies according to the level of house price itself. Unlike previous studies that estimate new housing supply based on linear relation with house price where a fixed value of price elasticity of housing supply is estimated, this study proposes a flexible price elasticity of housing supply that changes according to the level of house price. We support our findings by evaluating the significance of marginal effects.

The remainder of this paper is organized as follows. In section 1, we review empirical studies of the key variables of housing supply and the nonlinear response of housing market. Section 2 lays out the empirical model, econometric method and data used in this study. The empirical results and discussions are presented in section 3 while the last section concludes the study. 


\section{Literature review}

Numerical studies suggest that housing starts depending on house price, construction cost and interest rate (Meen, 2000, 2005; Wigren \& Wilhelmsson, 2007; Ball et al., 2010; McLaughlin, 2011). House price is always found to be the main determinant of housing starts that shows a positive coefficient. House price affects the incentive to build new houses and maintain the existing stock of housing (Caldera \& Johansson, 2013). Construction cost and interest rate are input prices in housing starts function and are found to have negative effects on housing starts.

Besides that, there has been considerable interest in the role played by housing supply in explaining differences in house prices. The extent of price adjustment will depend on the magnitude of housing supply price elasticity. Grimes and Aitken (2010) found that places with more elastic housing supply tend to experience lower house price appreciation. Although places with elastic supply of housing tend to experience smaller price increases, Glaeser et al. (2008) argued that social welfare losses may be higher in more elastic areas because houses are overbuilt during period of bubble. On the other hand, both Malpezzi and Maclennan (2001) and Meen (2005) found that housing market in the UK is less elastic compared to the US. Green et al. (2005) found that highly regulated and high density areas exhibit low supply elasticities. Other studies that attempted to estimate the price elasticity of housing supply include Mayo and Sheppard (1996), Blackley (1999), Ball et al. (2010), Caldera and Johansson (2013), McLaughlin (2011), Gitelman and Otto (2012), and Oikarinen et al. (2015).

Some other authors have attempted to examine the spillover effects within housing submarkets and the volatility clustering of house prices. Bangura and Lee (2019) divided the housing markets in Greater Sydney into lowpriced and high-priced submarkets and found spillover effect of housing submarkets. The findings of this study support the equity transfer hypothesis where house price changes in low-priced submarket will result in house price changes in high-priced submarket. The low-price submarket behaves as a price leader by reacting to changes in economic fundamentals. Besides the spillover effect of house prices, Weng and Gong (2017) investigated the volatility spillover of housing returns. They found regional housing markets in China demonstrate strong co-movement and volatility spillover with positive leverage effect, showing that investors in housing markets react more strongly to bad news than good news. While these studies show that housing submarkets are interrelated, Lee and Reed (2014) examined the volatility of Australian house prices based on component-generalized autoregressive conditional heteroskedasticity (C-GARCH) which decompose house prices into a permanent component and a transitory component. They found that the transitory volatility has greater impact than the permanent volatility while both volatilities capture different sets of macroeconomic information. The implication of this study is that the housing markets respond differently to macroeconomic shocks.
Furthermore, there are studies that attempted the volatility clustering of housing supply. Lee and Jin (2011) argued that volatility of housing starts is varying over time and shows an ARCH effect. They examined the volatility linkages between Australian housing supply and macroeconomic variables i.e. interest rate, construction cost and house price. This study shows three important findings based on GARCH-M model: (1) there is strong volatility clustering in housing starts series, (2) high level of uncertainty is associated with lower housing starts, and (3) volatility of interest rate and construction cost are important determinants of housing starts volatility. Prior to the study of Lee and Jin (2011), Bulan et al. (2009) has employed $\operatorname{GARCH}(1,1)$ model to measure uncertainty of condominium construction in Vancouver from 1979-1998. Results show that increased uncertainty in real estate prices delays condominium constructions. Miles (2009) has also investigated the effects of uncertainty on US housing starts using GARCH-M model. The results show that uncertainty has significant negative impact on housing starts.

The above studies have attempted to examine different aspects of housing supply including the price elasticity of housing supply and the volatility clustering of housing starts. These empirical works are mainly focus on the advanced economies such as US, UK and Australia with limited studies from the emerging countries e.g. Malaysia. The only exceptions are Mayo and Sheppard (1996) and Malpezzi and Mayo (1997) that presented comparison of housing supply for three emerging countries i.e. Malaysia, Thailand and Korea. Results of these two studies show that housing supply in Malaysia was price inelastic during 1980s due to restrictive planning systems in the country.

Another strand of literature deals with new housing supply at firm or housing developer level. For instance, Ball et al. (2010) found that supply elasticities are greater for large firms than for small firms in the UK. This suggests that larger housing developers have the ability to react responsively to an increase in demand by increasing their output levels and thus significantly increase their market shares. Housing developers are heterogeneous due to differences in land holdings, capital intensity, production technology and cost of borrowing (Leishman, 2015). Therefore, housing development process are complex, and it involves housing developers' decisions on land purchases, planning and permission applications, commencement of development project and the duration of housing completions.

Some other studies also examine housing market in nonlinear frameworks. For instance, Holly and Jones (1997) consider real income, lending, population, housing stock and interest rates as the explanatory variables of house prices in asymmetric error correction model. The results revealed that real income is the most important variable. House prices in the UK adjust asymmetrically where house prices respond more rapidly when they are above the longrun equilibrium compared to when they are below.

Pryce (1999) compared elasticity of housing supply between boom and slump and tested the backward-bending supply curve for new houses. They found that the supply 
curve for new houses bends backward during boom. The response of housing supply to house price is relatively slow leading to low supply elasticity. The average price elasticity of supply is lower during boom than the bust.

Glaeser and Gyourko (2005) discussed the kinked supply curve of housing market whereby supply is highly elastic when house price is equal or greater than construction cost and highly inelastic when house price is less than construction cost. They presented a durable housing model that predicts different asymmetric responses of population and house prices due to exogenous shocks. The model explains that negative shocks that lead to declining cities will have small effect on population but large effects on house prices. Conversely, positive shocks leading to urban growth will have large effects on population but small effects on house prices.

More recent studies such as Ma et al. (2017) examined the impact of property prices on residential construction output in Australia capital cities. Although they pointed out an inverted-U shaped relationship between construction output and economic developments, they found that local economic development increases residential construction output in the Australia capital cities due to higher employment and immigration in residential construction industry.

On the other hand, Glaeser and Gyourko (2018) explained three different types of supply curves in the US housing market. First, a relatively flat upward-sloping supply curve (highly elastic) in which house prices is equal to the minimum profitable production cost. This situation is commonly observed in growing population and economies. Second, a relatively inelastic supply curve in which house prices is considerably above the minimum profitable production cost. In this situation, housing market is highly regulated and restricts developers to bring on new construction in growing population and economies. Third, a kinked housing supply curve in which house prices is equal to the minimum profitable production cost even though with a growing demand but prices fall below the minimum profitable production cost following a negative demand shock.

In conclusion, there are increasing works that investigate housing supply in nonlinear frameworks but the studies are limited. While Glaeser and Gyourko (2005 and 2018) address the development of kinked housing supply curve in the US market, both Pryce (1999) and Ma et al. (2017) acknowledge the existence of an inverted-U shape housing supply curve. None of these authors provides empirical evidence to address the nonlinear response of housing supply to house price. We believe that a model should be developed to enhance the understanding of housing supply.

\section{Empirical model, methodology and data}

\subsection{Empirical model}

We select the repressors of housing supply based on Meen (2005). Following this study, the empirical linkages be- tween housing supply and house price is formulated using the following linear equation:

$$
H S_{i t}=\beta_{0}+\beta_{1} H P_{i t}+\beta_{2} C C_{i t}+\beta_{3} I R_{i t}+\varepsilon_{i t},
$$

where: HS is the housing starts; HP is the house price; CC is construction cost and IR is interest rate; $\varepsilon_{\mathrm{it}}$ is the error term; $i$ is the individual group index that represents different type of houses and $t$ is the time index. All variables are transformed into natural logarithm except interest rate.

To evaluate the non-linear relation between housing supply and house price, we include the squared term of house price $\left(\mathrm{HP}^{2}\right)$ into Equation (1).The new model is specified as follows:

$$
H S_{i t}=\beta_{0}+\beta_{1} H P_{i t}+\beta_{2} H P_{i t}^{2}+\beta_{3} C C_{i t}+\beta_{4} I R_{i t}+\varepsilon_{i t} \text {. }
$$

If $\beta_{1}$ and $\beta_{2}$ coefficients are positive and negative, respectively, and both are statistically significant, then there is an inverted U-shaped relation between housing supply and house price. On the other hand, if $\beta_{1}$ and $\beta_{2}$ coefficients are negative and positive, respectively, and both are statistically significant, then there is a U-shaped relationship.

From Equation (2), the marginal effect of increasing housing supply due to house price can be calculated by examining the partial derivative of housing supply as follows:

$$
\frac{\delta H S_{i t}}{\delta H P_{i t}}=\beta_{1}+2 \beta_{2} H P_{i t} \text {. }
$$

Equation (3) states that change in housing supply due to change in house price (i.e. the price elasticity of housing supply) depend on house price itself. To evaluate the significance of marginal effect of house price on housing supply, we compute the standard error as suggested by Brambor et al. (2006). The calculated marginal effect refers to the long-run parameter of HP.

\subsection{Econometric methodology}

Since our panel dataset involves a relatively large number of time series than cross-section $(\mathrm{T}>\mathrm{N})$, we employ mean group (MG) and pooled mean group (PMG) estimators proposed by Pesaran and Smith (1995) and Pesaran et al. (1999), respectively, to estimate $\beta_{1}$ and $\beta_{2}$ coefficients stipulated in Equation (2).

In MG and PMG estimation, Equation (2) can be written in an unrestricted error correction ARDL representation as follows:

$$
\begin{aligned}
& \Delta H S_{i t}=\Phi_{i} H S_{i, t-1}+\Phi_{1 i} H P_{i, t-1}+\Phi_{2 i} H P_{i, t-1}^{2}+ \\
& \Phi_{3 i} C C_{i, t-1}+\Phi_{4 i} I R_{i, t-1}+\sum_{j=1}^{p-1} \delta_{i j} \Delta H S_{i, t-j}+ \\
& \sum_{j=0}^{q-1} \lambda_{1 i j} \Delta H P_{i, t-j}+\sum_{j=0}^{q-1} \lambda_{2 i j} \Delta H P_{i, t-j}^{2}+\sum_{j=0}^{q-1} \lambda_{3 i j} \Delta C C_{i, t-j} \\
& +\sum_{j=0}^{q-1} \lambda_{4 i j} \Delta I R_{i, t-j}+\tau D_{t}+\eta_{i}+\mu_{i t}
\end{aligned}
$$

for $i=1,2, \ldots, N ; t=1,2, \ldots, T$, 
where: $\phi_{i}$ is the coefficient on the lagged dependent variable; $\varphi_{k i}$ is the coefficients on the lagged explanatory variables, for $k=1,2,3,4 ; \delta_{i j}$ is the coefficient on the lagged first difference of dependent variable; $\lambda_{k i j}$ is the coefficients on the lagged first differences of explanatory variables for $k=1,2,3,4 . D_{t}$ represents a potential structural break during the period. $D_{t}$ is defined as a dummy variable with a value of 1 after the breakpoint and 0 otherwise. We use Zivot and Andrew unit root test to identify breakpoint of each housing supply series. $\eta_{i}$ is the fixed effect (groupspecific effect) which allows the short-run coefficients to vary across groups. The disturbance term $\mu_{i t}$ in the ARDL model is assumed to be independently distributed across $i$ and $\mathrm{t}$ with zero means and variances $\sigma_{i}^{2}>0$. When $\phi_{i}<0$ for all $i$, a long-run relationship between the dependent variable $\left(\mathrm{HS}_{\mathrm{it}}\right)$ and the explanatory variables $\left(\mathrm{HP}_{\mathrm{it}}, \mathrm{HP}^{2}{ }_{\mathrm{it}}\right.$, $\left.\mathrm{CC}_{\mathrm{it}}, \mathrm{IR}_{\mathrm{it}}\right)$ is given as:

$$
H S_{i t}=\beta_{0}+\beta_{1} H P_{i t}+\beta_{2} H P_{i t}^{2}+\beta_{3} C C_{i t}+\beta_{4} I R_{i t}+\varepsilon_{i t},
$$

where: $\beta_{k}=-\varphi_{k i} / \phi_{i}$ is the long-run coefficient for $k=1,2$, 3 , 4. Equation (6) can be represented in an error correction model as follows:

$$
\begin{aligned}
& \Delta H S_{i t}=\rho \varepsilon_{i, t-1}+\sum_{j=1}^{p-1} \delta_{i j} \Delta H S_{i, t-j}+\sum_{j=0}^{q-1} \lambda_{1 i j} \Delta H P_{i, t-j}+ \\
& \sum_{j=0}^{q-1} \lambda_{2 i j} \Delta H P_{i, t-j}^{2}+\sum_{j=0}^{q-1} \lambda_{3 i j} \Delta C C_{i, t-j}+\sum_{j=0}^{q-1} \lambda_{4 i j} \Delta I R_{i, t-j}+ \\
& \tau D_{t}+\eta_{i}+\mu_{i t},
\end{aligned}
$$

where: $\varepsilon_{i t-1}$ is the error correction term given by Equation (6), and $\phi_{i}$ is the coefficient of error correction term measuring the speed of adjustment towards long-run equilibrium.

The PMG estimator proposed by Pesaran et al. (1999) allows the intercepts, short-run coefficients and error variances to differ across groups but assumes homogenous longrun coefficients. The long-run coefficients in Equation (6) are common across groups while the group-specific shortrun coefficients are varies due to the $\eta_{i}$ term that measures group-specific effect. On the other hand, in the MG estimator proposed by Pesaran and Smith (1995), the averages of the group-specific coefficients are calculated by separately estimating the regressions for each group. Hence, the MG estimator allows the intercepts, long-run and short-run coefficients as well as the error variances to differ across groups.

After estimating the MG and PMG models, Hausman test (Hausman, 1978) is conducted to test the homogeneity of long-run coefficients. This allows us to choose the preferred model between MG and PMG. Under the null hypothesis of Hausman test, the long-run coefficients are equal or homogenous slopes for all groups. Pesaran et al. (1999) argued that when slope homogeneity holds, MG estimator provides consistent but inefficient estimates of the long-run coefficients, however, the PMG estimators are consistent and efficient. As such, insignificance of Hausman test shows that PMG is more efficient.

\subsection{Data}

The data used in this study is quarterly and covers the period from 2002Q3 to 2016Q4 $(\mathrm{T}=58)$. We employ 4 types of housing starts namely detached, high-rise, semi-detached and terraced houses in Malaysia $(\mathrm{N}=4)$. This provides a panel dataset of 232 observations. We use housing starts as a proxy of housing supply. According to the Malaysian Valuation and Property Service Department (JPPH) (2009), housing starts are buildings where the foundation and footing works of low-rise buildings or works below ground level including piling and foundation of high-rise buildings are started. Four types of housing starts are collected from National Property Information Centre (NAPIC) and these data are measured in terms of the number of houses. Besides that, house price is measured by house prices index. We collect house price indexes for the four types of houses from NAPIC. We employ Building material cost index (BMCI) which is published by Construction Industry Development Board Malaysia to proxy for construction cost. BMCI for residential sector is used in this study. BMCI measures the changes in transaction price of building material input in residential construction activities ${ }^{3}$. Interest rate is measured by base lending rate (BLR) which is collected from Monthly Statistical Bulletin published by Bank Negara Malaysia. BLR was the main reference rate for housing loans in Malaysia prior to 2 January 2015.

\section{Empirical results}

\section{Descriptive statistics}

The descriptive statistics for the data used in this study are presented in Table 1. The standard deviation of housing starts is the highest among the variables used in the study. This shows that housing starts are quite dispersed around the means compared to house price.

Table 1. Descriptive statistics

\begin{tabular}{|c|c|c|}
\hline & Mean & Std. Dev. \\
\hline HS & 8.4834 & 1.1593 \\
\hline HP & 5.0236 & 0.2768 \\
\hline CC & 4.4304 & 0.1801 \\
\hline IR & 1.5975 & 0.0934 \\
\hline
\end{tabular}

Notes: HS: housing starts; HP: house price; CC: construction cost; IR: interest rate. All variables except IR are presented in natural logarithm form.

\section{Panel unit root tests}

We conduct three unit root tests: Levin, Lin, and Chu (LLC) (Levin et al., 2002), Im, Pesaran, and Shin (IPS)

\footnotetext{
3 We acknowledge the importance of labour cost as a relevant variable in new housing supply. Unfortunately, the variable is omitted due to unavailability of data.
} 
Table 2. Panel unit root test

\begin{tabular}{|c|c|c|c|c|c|c|}
\hline \multirow{2}{*}{} & \multicolumn{2}{|c|}{ LLC } & \multicolumn{2}{c|}{ IPS } & \multicolumn{2}{c|}{ ADF-Fisher } \\
\cline { 2 - 7 } & Level & 1 st diff & Level & 1 st diff & Level & 1 st diff \\
\hline HS & $-2.399^{* * *}$ & $-12.496^{* * *}$ & -0.892 & $-13.209^{* * *}$ & 9.775 & $121.942^{* * *}$ \\
\hline HP & -0.897 & $-8.517^{* * *}$ & 1.866 & $-8.618^{* * *}$ & 1.475 & $73.789^{* * *}$ \\
\hline CC & $-1.977^{* *}$ & $-13.385^{* * *}$ & $-1.348^{*}$ & $-10.447^{* *}$ & 11.664 & $93.092^{* * *}$ \\
\hline IR & -0.090 & $-4.519^{* * *}$ & $-1.703^{* *}$ & $-5.254^{* * *}$ & $13.630^{*}$ & $40.354^{* * *}$ \\
\hline
\end{tabular}

Notes: ${ }^{* * *},{ }^{* *}$ and ${ }^{*}$ indicate statistically significant at $1 \%, 5 \%$ and $10 \%$ respectively.

(Im et al., 2003) and ADF-Fisher tests. The results are presented in Table 2. The three unit root tests reports inconsistent results for HS, CC and IR. Only HP is consistently reported as integrated at order one i.e. I(1). HS is tested to be I(0) by LLC but I(1) by IPS and ADF-Fisher. Both LLC and IPS confirm CC to be I(0) but ADF-Fisher shows CC as I(1). IR is tested as I(1) by LLC but I(0) by IPS and ADF-Fisher. However, we confirm that none of the series is $\mathrm{I}(2)$ which allow us to proceed the analysis with PMG.

Besides that, we also perform Zivot and Andrew unit root test on each HS series to detect possible existence of structural break endogenously. The results of ZA unit root test and the structural breakpoint of each type of housing supply are reported in Table 3.

We attempt to control for structural change by adding a dummy variable $\left(D_{t}\right)$ into the model. $D_{t}$ takes value of 1 after the breakpoint as detected by Zivot and Andrew unit root test and 0 otherwise.

\section{Panel cointegration}

The results from panel unit root tests reveal that all variables are non-stationary in levels and become stationary in first differences which show that all variables are integrated of order one I(1). Hence, the variables are possibly cointegrated. Panel cointegration tests are employed to test the hypothesis that a long-run relationship exist among the variables. Pedroni $(1999,2004)$ and Kao (1999) propose several tests to examine the existence of cointegration which test the null hypothesis of no cointegration against the alternative hypothesis of cointegration. Pedroni (1999, 2004) propose seven panel cointegration test statistics e.g. four panel statistics that assumes homogeneity of AR term and three group statistics that allows for heterogeneity of AR term. Kao (1999) test follows the same approach as the Pedroni test but specifies the cross-section intercepts and homogenous regression coefficient. While both Pedroni and Kao tests assume a single cointegrating vector, Maddala and Wu (1999) propose a Fisher cointegration test based on the framework of Johansen (1988) cointegration trace test and maximum eigenvalue test.

Table 4 summarizes the results of panel cointegration tests using Pedroni, Kao and Fisher statistics. All the seven Pedroni tests reject the null hypothesis of no cointegra-
Table 3. Zivot and Andrew unit root test

\begin{tabular}{|c|c|c|}
\hline & Level & Breakpoint \\
\hline HSD & $-3.9907^{*}$ & $2014 \mathrm{Q} 3$ \\
\hline HSH & $-4.7118^{* * *}$ & $2011 \mathrm{Q} 1$ \\
\hline HSS & $-5.4533^{* * *}$ & $2011 \mathrm{Q} 2$ \\
\hline HST & $-4.0235^{*}$ & $2008 \mathrm{Q}$ \\
\hline
\end{tabular}

Notes: Zivot and Andrew test was performed with break at both intercept and trend. HSD denotes detached housing supply; HSH denotes highrise housing supply; HSS denotes semi-detached housing supply; HST denotes terraced housing supply. ${ }^{* * *}$ and ${ }^{*}$ represents $1 \%$ and $10 \%$ level of significance.

Table 4. Panel cointegration tests

\begin{tabular}{|c|c|c|}
\hline Cointegration tests & & Statistics \\
\hline \multicolumn{3}{|c|}{ 1. Pedroni cointegration tests } \\
\hline Panel v-statistic & \multicolumn{2}{|r|}{$1.3670^{*}$} \\
\hline Panel rho-statistic & \multicolumn{2}{|r|}{$-4.5387^{* * *}$} \\
\hline Panel PP-statistics & \multicolumn{2}{|r|}{$-4.9977^{* * *}$} \\
\hline Panel ADF-statistics & \multicolumn{2}{|r|}{$-1.9260^{* *}$} \\
\hline Group rho-statistic & \multicolumn{2}{|r|}{$-4.6917^{* * *}$} \\
\hline Group PP-statistic & \multicolumn{2}{|r|}{$-6.1026^{* * *}$} \\
\hline Group ADF-statistic & \multicolumn{2}{|r|}{$-1.8287^{* *}$} \\
\hline 2. Kao cointegration test & \multicolumn{2}{|r|}{$-2.4461^{* * *}$} \\
\hline 3. Fisher cointegration & Trace test & Max. Eigenvalue test \\
\hline None & $102.1^{\star \star \star}$ & $59.06^{* * *}$ \\
\hline At most 1 & $53.10^{\star * \star}$ & $39.86^{* * *}$ \\
\hline At most 2 & $21.84^{* * *}$ & 12.21 \\
\hline At most 3 & $16.40^{* *}$ & $14.82^{*}$ \\
\hline At most 4 & 12.86 & 12.86 \\
\hline
\end{tabular}

Notes: ${ }^{* *},{ }^{* *}$ and ${ }^{*}$ indicate rejection of the null hypothesis of no cointegration at $1 \%, 5 \%$ and $10 \%$ level of significance respectively.

tion using both the panel and group statistics. Moreover, Kao cointegration test also rejects the null hypothesis of no cointegration. The Fisher cointegration test suggests that there is at least two cointegrating relationship among the variables according to maximum eigenvalue test. Thus, panel cointegration tests results strongly suggest that there is a long-run relationship among the variables. 


\section{MG and PMG for linear model}

We attempt to compare the results with and without the squared term of house price for both MG and PMG estimations. The empirical results of linear model (Equation (1)) using MG and PMG estimations are presented in Table 5. The results indicate that house price is not a statistically significant determinant for housing starts. The result clearly shows misspecification of house price as a linear relationship with housing starts and it is in line with Pryce (1999).

\section{MG and PMG for inverted U-shaped model}

Table 6 reports the estimates of Equation (2) using MG and PMG. The Hausman test statistic fails to reject the null hypothesis of slope homogeneity and thus PMG is more efficient. Since PMG is a preferred model, we therefore focus our discussion on the non-linear relationship between housing supply and house price based on PMG results.

The empirical results suggest that house price and its squared term are significant determinants of housing starts in PMG model. The coefficients of house price and its squared term are positive and negative, respectively, in the long-run. This implies that house price and housing starts have a nonlinear inverted U-shaped relationship, where house price increases housing starts up to a point, and then it shows an inverse impact on housing starts.

The results also show a cointegration relationship between housing starts and the explanatory variables. This is supported by the negative sign and statistically significance of the coefficient of lagged error correction term. We find that the speed of adjustment reported by PMG is $51.4 \%$. Given the full adjustment occurs at $100 \%$, the system will take about 2 quarters to revert back to its long- run equilibrium if there is a short-run deviation. In the short-run, the coefficients of house price, squared term of house price, construction cost and interest rate are not statistically significant at $5 \%$ level. Since housing supply is perfectly inelastic in the short-run and that housing supply is based on current completion which cannot be changed in a short-period of time, the insignificance of the explanatory variables in the short-run is not surprising. In the studies of both McLaughlin (2011) and Mayer and Somerville (2000a and 2000b), construction cost and interest rate are found to insignificantly affect housing starts in the short-run.

Since the relationship between housing starts and house price is inverted U-shaped, we proceed to compute the marginal effect of changes in housing starts due to changes in house price. Table 7 shows the marginal effects of house price on housing supply evaluated at the minimum, mean, maximum and threshold levels of house prices. The results show that the marginal effect changes at different levels of house prices i.e. it is positive at lower level of house price and turn to negative at higher level of house price after the threshold point. For instance, at the minimum of house price, the marginal effect of house price on housing supply is 2.3052 . This implies that if house price increases by $1 \%$, new housing supply will increase by $2.31 \%$. The increase in house price will continue to encourage more housing supply until the threshold level. At threshold level, the marginal effect is zero. This means that the increase in house price will not create any additional supply of new housing. Conversely, after the threshold level, any additional increase in house price will lower the new housing supply. For instance, at the maximum of house price, the marginal effect is -1.59 . This shows that when house price increases by $1 \%$, new housing supply will decline by $1.59 \%$.

Table 5. Results of linear relation between housing starts and house price

$\Delta H S_{i t}=\rho \varepsilon_{i, t-1}+\sum_{j=0}^{q-1} \delta_{i j} \Delta H S_{i, t-j}+\sum_{j=0}^{q-1} \lambda_{1 i j} \Delta H P_{i, t-j}+\sum_{j=0}^{q-1} \lambda_{2 i j} \Delta C C_{i, t-j}+\sum_{j=0}^{q-1} \lambda_{3 i j} \Delta I R_{i, t-j}+\tau D_{t}+\eta_{i}+\mu_{i t}$

where: $\varepsilon_{i t}=H S_{i t}-\beta_{1} H P_{i t}-\beta_{2} C C_{i t}-\beta_{3} I R_{i t}$

\begin{tabular}{|l|c|c|}
\hline & MG & PMG \\
\hline Optimum lag & $(1,1,1,1)$ & $0.2569(1.21)$ \\
\hline Long-run coefficients & & $-0.4341(-1.58)$ \\
\hline$\beta_{1}$ & $0.1084(0.34)$ & $0.2524(0.81)$ \\
\hline$\beta_{2}$ & $-0.6354(-0.86)$ & $-0.5593(-9.57)^{* *}$ \\
\hline$\beta_{3}$ & $0.8109(1.78)^{*}$ & $0.9415(1.96)^{*}$ \\
\hline Short-run coefficients & & $0.0119(0.03)$ \\
\hline$\rho$ & $-0.6872(-29.66)^{* * *}$ & $0.5958(1.56)$ \\
\hline$\lambda_{1}$ & $1.2014(2.06)^{* *}$ & $-0.0377(-0.45)$ \\
\hline$\lambda_{2}$ & $-0.2478(-0.49)$ & \\
\hline$\lambda_{3}$ & $0.4536(1.31)$ & $\left.\right|^{*}$ \\
\hline$\tau$ & $0.0272(0.18)$ & $\left.\right|^{*}$ \\
\hline
\end{tabular}

Notes: HS is the dependent variable. Figures in ( ) represents t-statistic. ${ }^{* *},{ }^{* *}$ and ${ }^{*}$ indicate statistically significant at $1 \%, 5 \%$ and $10 \%$ respectively. The optimum lag orders of the model are selected based on Schwarz Information Criteria (SIC) with a maximum lag of four. For HSD, $D_{t}$ takes value 1 from 2014Q3 to 2016Q4 and 0 otherwise. For HSH, $D_{t}$ takes value 1 from 2011Q1 to 2016Q4 and 0 otherwise. For HSS, $D_{t}$ takes value 1 from 2011Q2 to 2016Q4 and 0 otherwise. For HST, $D_{t}$ takes value 1 from 2008Q4 to 2016Q4 and 0 otherwise. The full results of MG and PMG that show the groupspecific effect are presented in Athe Supplementary material Table S1 and S2 respectively. 
Table 6. Results of non-linear relation between housing starts and house price

$$
\Delta H S_{i t}=\rho \varepsilon_{i, t-1}+\sum_{j=0}^{q-1} \delta_{i j} \Delta H S_{i, t-j}+\sum_{j=0}^{q-1} \lambda_{1 i j} \Delta H P_{i, t-j}+\sum_{j=0}^{q-1} \lambda_{2 i j} \Delta H P_{i, t-j}^{2}+\sum_{j=0}^{q-1} \lambda_{3 i j} \Delta C C_{i, t-j}+\sum_{j=0}^{q-1} \lambda_{4 i j} \Delta I R_{i, t-j}+\tau D_{t}+\eta_{i}+\mu_{i t}
$$

where: $\varepsilon_{i t}=H S_{i t}-\beta_{1} H P_{i t}-\beta_{2} H P_{i t}^{2}-\beta_{3} C C_{i t}-\beta_{4} I R_{i t}$

\begin{tabular}{|l|c|c|}
\hline & MG & PMG \\
\hline Optimum lag & $(1,1,1,1,1)$ & $2,1,1,1)$ \\
\hline Long-run coefficients & & $-2.1201(-3.22)^{* * *}$ \\
\hline$\beta_{1}$ & $7.4806(0.77)$ & $-1.2460(-3.29)^{* * *}$ \\
\hline$\beta_{2}$ & $-0.7242(-0.77)$ & $0.3807(1.46)$ \\
\hline$\beta_{3}$ & $-0.9543(-1.69)^{*}$ & \multicolumn{2}{|c|}{} \\
\hline$\beta_{4}$ & $0.7083(1.54)$ & $-0.6121(-6.91)^{* * *}$ \\
\hline Short-run coefficients & & $-46.7507(-2.05)^{* * *}$ \\
\hline$\rho$ & $-0.7348(-13.87)^{* * *}$ & $4.7213(2.09)^{* *}$ \\
\hline$\lambda_{1}$ & $-35.8078(-1.51)$ & $0.4300(1.52)$ \\
\hline$\lambda_{2}$ & $3.6790(1.57)$ & $0.3637(0.96)$ \\
\hline$\lambda_{3}$ & $-0.0757(-0.19)$ & $0.0154(0.15)$ \\
\hline$\lambda_{4}$ & $0.4009(1.20)$ & $0.82[0.94]$ \\
\hline$\tau$ & $0.0608(0.32)$ & \\
\hline Hausman test & & \\
\hline
\end{tabular}

Notes: HS is the dependent variable. Figures in ( ) represents t-statistic whereas figure in [ ] represents p-value. ${ }^{* * *},{ }^{* *}$ and ${ }^{*}$ indicate statistically significant at $1 \%, 5 \%$ and $10 \%$ respectively. $\mathrm{N} \times \mathrm{T}=232$ observations. The marginal effect values are computed using Equation (2) based on the HP descriptive statistics in Table 1. The optimum lag orders of the model are selected based on Schwarz Information Criteria (SIC) with a maximum lag of four. For HSD, $D_{t}$ takes value 1 from 2014Q3 to 2016Q4 and 0 otherwise. For HSH, $D_{t}$ takes value 1 from $2011 \mathrm{Q} 1$ to $2016 \mathrm{Q} 4$ and 0 otherwise. For HSS, $\mathrm{D}_{t}$ takes value 1 from 2011Q2 to 2016Q4 and 0 otherwise. For HST, $D_{t}$ takes value 1 from 2008Q4 to 2016Q4 and 0 otherwise. The full results of MG and PMG that show the group-specific effect are presented in the Supplementary material Table S3 and S4 respectively.

Table 7. Marginal effect of house price on housing supply

\begin{tabular}{|l|c|c|c|c|}
\hline \multirow{2}{*}{} & \multirow{2}{*}{ House price } & \multicolumn{2}{|c|}{ Marginal effect of house price on housing supply } \\
\cline { 3 - 5 } & & Marginal effect & Standard error & t-statistic \\
\hline Minimum & 4.6492 & $2.3052^{* * *}$ & 0.7640 & 3.017 \\
\hline Mean & 5.0236 & $0.7178^{* *}$ & 0.3181 & 2.256 \\
\hline Maximum & 5.5683 & $-1.5922^{* * *}$ & 0.5178 & -3.075 \\
\hline Threshold level & 5.1928 & 0.000 & 0.2069 & 0.000 \\
\hline
\end{tabular}

Note: Marginal effect $=\beta_{1}+2 \beta_{2} \mathrm{HP}$; the threshold level of house price is calculated by equating $\beta_{1}+2 \beta_{2}$ HP to zero and solve for HP; Std. error = $\sqrt{\operatorname{var}\left(\beta_{1}\right)+4 H P^{2} \operatorname{var}\left(\beta_{2}\right)+4 H P \operatorname{cov}\left(\beta_{1}, \beta_{2}\right)}$, t-statistic $=$ Marginal effect/Std. error; critical value-t at $1 \%: 2.2326,5 \%: 1.96,10 \% 1.645 .^{* * *}$ and $^{* *}$ indicate statistically significant at $1 \%$ and $5 \%$ levels respectively.

This finding implies that supply of new housing tends to fall at higher level of house price. When there is an increase in house price, demand for housing will fall and subsequently lead to a decline in new housing supply.

The above findings provide a strong empirical evidence to confirm the existence of inverted U-shaped supply curve in housing market for the case in Malaysia. Unlike other developed economies, housing supply in emerging markets has some unique characteristics such as properties overhang (Lee, 2014). Due to this reason, the inclusion of HP2 is more appropriate in modelling housing supply in the emerging countries. This study provides a founda- tion to develop more evidence of inverted U-shaped housing supply curve in different economies at international level especially for emerging and developing economies. Further evidence at international housing market should be conducted. In fact, the evidence of inverted U-shaped housing supply curve shows important policy implication in Malaysia. It implies that housing policymakers in the country have taken precautionary steps to address the issue of oversupply and overhang. The authorities of Malaysia are cautious in approving housing development projects with the aim to reduce the negative impact of properties overhang in the country. 


\section{Conclusions}

This paper has attempted to model housing supply and house price in a nonlinear framework based on panel data across four types of houses over the period from 2002Q3 to 2016Q4. In the linear model, HP has an insignificant result. This could be due to misspecification of $\mathrm{HP}$ as a linear relationship with housing starts. However, in the nonlinear model when the squared term of house price is included, both $\mathrm{HP}$ and $\mathrm{HP}^{2}$ are statistically significant. Construction cost and interest rate also significantly influence housing starts in a nonlinear framework. The marginal effects of house price also demonstrate that higher level of house price tends to lower housing starts. The findings of this study provide new evidence to the empirical study of McLaughlin (2011) and Gitelman and Otto (2012) where housing supply and house price are linearly related.

Our study suggests that the supply of housing does not develop in a linear form where an increase in house price is associated with an increase in housing supply indefinitely. However, it is cyclical where there is a downward trend in the supply of housing. Since new housing construction is closely related to the development controls and regulations, improper planning and development approvals may cause oversupply of housing in one period, which exists when there is an increase in unsold units and leads to property overhang. Subsequently, property developers will reduce the number of new housing constructions in the following periods. A further increase of house price above the threshold will lead to a fall in the new housing construction. As such, we suggest nonlinear framework where the squared term of house price should be used in modelling and estimating housing supply.

\section{Acknowledgements}

Research University Grant Scheme 1001/PSOSIAL/816302 by Universiti Sains Malaysia is acknowledged.

\section{References}

Alkay, E., Watkins, C., \& Keskin, B. (2018). Explaining spatial variation in housing construction activity in Turkey. International Journal of Strategic Property Management, 22(2), 119-130. https://doi.org/10.3846/ijspm.2018.443

Al-Masum, M. A., \& Lee, C. L. (2019). Modelling housing prices and market fundamentals: evidence from the Sydney housing market. International Journal of Housing Markets and Analysis, 12(4), 746-762.

https://doi.org/10.1108/IJHMA-10-2018-0082

Ball, M., Meen, G., \& Nygaard, C. (2010). Housing supply price elasticities revisited: evidence from international, national, local and company data. Journal of Housing Economics, 19, 255-268. https://doi.org/10.1016/j.jhe.2010.09.004

Bangura, M., \& Lee, C. L. (2019). House price diffusion of housing submarkets in Greater Sydney. Housing Studies, 1-32. https://doi.org/10.1080/02673037.2019.1648772

Barot, B., \& Yang, Z. (2002). House prices and housing investment in Sweden and the UK: econometric analysis for the period 1970-1998. Review of Urban \& Regional Development Studies, 14(2), 189-216.

https://doi.org/10.1111/1467-940X.00054

Blackley, D. M. (1999). The long-run elasticity of new housing supply in the United States: empirical evidence for 1950 to 1994. The Journal of Real Estate Finance and Economics, 18(1), 25-42. https://doi.org/10.1023/A:1007781228328

Brambor, T., Clark, W. R., \& Golder, M. (2006). Understanding interaction models: improving empirical analyses. Political Analysis, 14(1), 63-82. https://doi.org/10.1093/pan/mpi014

Bulan, L., Mayer, C., \& Somerville, C. T. (2009). Irreversible investment, real options, and competition: evidence from real estate development. Journal of Urban Economics, 65(3), 237-251. https://doi.org/10.1016/j.jue.2008.03.003

Caldera, A., \& Johansson, Å. (2013). The price responsiveness of housing supply in OECD countries. Journal of Housing Economics, 22(3), 231-249. https://doi.org/10.1016/j.jhe.2013.05.002

DiPasquale, D., \& Wheaton, W. C. (1994). Housing market dynamics and the future of housing prices. Journal of Urban Economics, 35, 1-27. https://doi.org/10.1006/juec.1994.1001

Gitelman, E., \& Otto, G. (2012). Supply elasticity estimates for the Sydney housing market. Australian Economic Review, 45(2), 176-190. https://doi.org/10.1111/j.1467-8462.2012.00679.x

Glaeser, E. L., \& Gyourko, J. (2005). Urban decline and durable housing. Journal of Political Economy, 113(2), 345-375. https://doi.org/10.1086/427465

Glaeser, E. L., Gyourko, J., \& Saiz, A. (2008). Housing supply and housing bubbles. Journal of Urban Economics, 64, 198-217. https://doi.org/10.1016/j.jue.2008.07.007

Glaeser, E., \& Gyourko, J. (2018). The economic implications of housing supply. Journal of Economic Perspectives, 32(1), 3-30. https://doi.org/10.1257/jep.32.1.3

Grimes, A., \& Aitken, A. (2010). Housing supply, land costs and price adjustment. Real Estate Economics, 38(2), 325-353. https://doi.org/10.1111/j.1540-6229.2010.00269.x

Green, R. K., Malpezzi, S., \& Mayo, S. K. (2005). Metropolitanspecific estimates of the price elasticity of supply of housing, and their sources. American Economic Review, 95(2), 334339. https://doi.org/10.1257/000282805774670077

Hausman, J. A. (1978). Specification tests in econometrics. Econometrica, 46(6), 1251-1271. https://doi.org/10.2307/1913827

Holly, S., \& Jones, N. (1997). House prices since the 1940s: cointegration, demography and asymmetries. Economic Modelling, 14(4), 549-565. https://doi.org/10.1016/S0264-9993(97)00009-6

Im, K. S., Pesaran, M. H., \& Shin, Y. (2003). Testing for unit roots in heterogeneous panels. Journal of Econometrics, 115(1), 5374. https://doi.org/10.1016/S0304-4076(03)00092-7

Johansen, S. (1988). Statistical analysis of cointegration vectors. Journal of Economic Dynamics and Control, 12(2-3), 231-254. https://doi.org/10.1016/0165-1889(88)90041-3

Kao, C. (1999). Spurious regression and residual-based tests for cointegration in panel data. Journal of Econometrics, 90(1), 1-44. https://doi.org/10.1016/S0304-4076(98)00023-2

Lee, C. L, \& Jin, X. H. (2011). Exploring Australian housing supply volatility. Pacific Rim Property Research Journal, 17(4), 634-651. https://doi.org/10.1080/14445921.2011.11104346

Lee, C. L. (2014). The inflation-hedging characteristics of Malaysian residential property. International Journal of Housing Markets and Analysis, 7(1), 61-75.

https://doi.org/10.1108/IJHMA-10-2012-0053

Lee, C. L., \& Reed, R. (2014). Volatility decomposition of Australian housing prices. Journal of Housing Research, 23(1), 21-43. 
Leishman, C. (2015). Housing supply and suppliers: are the microeconomics of housing developers important? Housing Studies, 30(4), 580-600.

https://doi.org/10.1080/02673037.2015.1021767

Levin, A., Lin, C. F., \& Chu, C. S. J. (2002). Unit root tests in panel data: asymptotic and finite-sample properties. Journal of Econometrics, 108(1), 1-24.

https://doi.org/10.1016/S0304-4076(01)00098-7

Ma, L., Liu, C., \& Reed, R. (2017). The impacts of residential construction and property prices on residential construction outputs: an inter-market equilibrium approach. International Journal of Strategic Property Management, 21(3), 296-306. https://doi.org/10.3846/1648715X.2016.1255675

Maddala, G. S., \& Wu, S. (1999). A comparative study of unit root tests with panel data and a new simple test. Oxford Bulletin of Economics and Statistics, 61(S1), 631-652. https://doi.org/10.1111/1468-0084.0610s1631

Malpezzi, S., \& Maclennan, D. (2001). The long-run price elasticity of supply of new residential construction in the United States and the United Kingdom. Journal of Housing Economics, 10(3), 278-306. https://doi.org/10.1006/jhec.2001.0288

Malpezzi, S., \& Mayo, S. K. (1997). Getting housing incentives right: a case study of the effects of regulation, taxes and subsidies on housing supply in Malaysia. Land Economics, 73(3), 372-391. https://doi.org/10.2307/3147174

Mayo, S., \& Sheppard, S. (2001). Housing supply and the effects of stochastic development control. Journal of Housing Economics, 10(2), 109-128. https://doi.org/10.1006/jhec.2001.0283

Mayer, C. J., \& Somerville, C. T. (2000a). Residential construction: using the urban growth model to estimate housing supply. Journal of Urban Economics, 48, 85-109.

https://doi.org/10.1006/juec.1999.2158

Mayer, C. J., \& Somerville, C. T. (2000b). Land use regulation and new construction. Regional Science and Urban Economics, 30, 639-662.

https://doi.org/10.1016/S0166-0462(00)00055-7

Mayo, S., \& Sheppard, S. (1996). Housing supply under rapid economic growth and varying regulatory stringency: an international comparison. Journal of Housing Economics, 5(3), 274-289. https://doi.org/10.1006/jhec.1996.0014

McLaughlin, R. B. (2011). New housing supply elasticity in Australia: a comparison of dwelling types. The Annals of Regional Science, 48(2), 595-618.

https://doi.org/10.1007/s00168-011-0491-z

Meen, G. (2000). Housing cycles and efficiency. Scottish Journal of Political Economy, 47(2), 114-140.

https://doi.org/10.1111/1467-9485.00156

Meen, G. (2005). On the economics of the Barker Review of housing supply. Housing Studies, 20(6), 949-971. https://doi.org/10.1080/02673030500291082

Miles, W. (2009). Irreversibility, uncertainty and housing investment. Journal of Real Estate Finance and Economics, 38(2), 173-182. https://doi.org/10.1007/s11146-007-9087-x

Neto, M. S. (2005). Analysis of the determinants of new housing investment in Spain. Housing, Theory and Society, 22(1), 18-31. https://doi.org/10.1080/14036090510032718

Oikarinen, E., Peltola, R., \& Valtonen, E. (2015). Regional variation in the elasticity of supply of housing, and its determinants: the case of a small sparsely populated country. Regional Science and Urban Economics, 50, 18-30.

https://doi.org/10.1016/j.regsciurbeco.2014.10.004

Ooi, J. T. L., \& Le, T. T. T. (2012). New supply and price dynamics in the Singapore housing market. Urban Studies, 49(7), 1435-1451. https://doi.org/10.1177/0042098011415718
Pedroni, P. (1999). Critical values for cointegration tests in heterogeneous panels with multiple regressors. Oxford Bulletin of Economics and Statistics, 61(S1), 653-670.

https://doi.org/10.1111/1468-0084.61.s1.14

Pedroni, P. (2004). Panel cointegration: asymptotic and finite sample properties of pooled time series tests with an application to the PPP hypothesis. Econometric Theory, 20(3), 597-625. https://doi.org/10.1017/S0266466604203073

Pesaran, M. H., \& Smith, R. (1995). Estimating long-run relationships from dynamic heterogeneous panels. Journal of Econometrics, 68(1), 79-113. https://doi.org/10.1016/0304-4076(94)01644-F

Pesaran, M. H., Shin, Y., \& Smith, R. P. (1999). Pooled mean group estimation of dynamic heterogeneous panels. Journal of the American Statistical Association, 94(446), 621-634. https://doi.org/10.1080/01621459.1999.10474156

Poterba, J. M. (1984). Tax subsidies to owner-occupied housing: an asset-market approach. Quarterly Journal of Economics, 99(4), 729-752. https://doi.org/10.2307/1883123

Pryce, G. (1999). Construction elasticities and land availability: a two-stage least-squares model of housing supply using the variable elasticity approach. Urban Studies, 36(13), 22832304. https://doi.org/10.1080/0042098992421

Rangel, G. J., Ng, J. W. J., Murugasu, T. T., \& Poon, W. C. (2019). Measuring Malaysian housing affordability: the lifetime income approach. International Journal of Housing Markets and Analysis, 12(5), 966-984.

https://doi.org/10.1108/IJHMA-02-2019-0023

Stevenson, S., \& Young, J. (2014). A multiple error-correction model of housing supply. Housing Studies, 29(3), 362-379. https://doi.org/10.1080/02673037.2013.803040

Tan, T. H. (2010). The effects of housing characteristics on neighbourhood stability of homeownership. International Journal of Business and Emerging Markets, 2(3), 286-304. https://doi.org/10.1504/IJBEM.2010.033380

Tan, T. H. (2011). Sustainability and housing provision in Malaysia. Journal of Strategic Innovation and Sustainability, 7(1), 62-71.

Teck-Hong, T. (2011). Neighborhood preferences of house buyers: the case of Klang Valley, Malaysia. International Journal of Housing Markets and Analysis, 4(1), 58-69. https://doi.org/10.1108/17538271111111839

Tan, T. H. (2012). Housing satisfaction in medium-and high-cost housing: the case of Greater Kuala Lumpur, Malaysia. Habitat International, 36(1), 108-116. https://doi.org/10.1016/j.habitatint.2011.06.003

Taltavull de La Paz, P., \& Gabrielli, L. (2015). Housing supply and price reactions: a comparison approach to Spanish and Italian markets. Housing Studies, 30(7), 1036-1063. https://doi.org/10.1080/02673037.2015.1006183

Tse, R. Y., Ho, C. W., \& Ganesan, S. (1999). Matching housing supply and demand: an empirical study of Hong Kong's market. Construction Management \& Economics, 17(5), 625-633. https://doi.org/10.1080/014461999371231

Valuation and Property Services Department (JPPH). (2012). Malaysia Property Market Report 2012. Putrajaya.

Valuation and Property Services Department (JPPH). (2015). Malaysia Property Market Report 2015. Putrajaya.

Wigren, R., \& Wilhelmsson, M. (2007). Housing stock and price adjustments in 12 West European countries between 1976 and 1999. Housing, Theory and Society, 24(2), 133-154. https://doi.org/10.1080/14036090601119589

Weng, Y., \& Gong, P. (2017). On price co-movement and volatility spillover effects in China's housing markets. International Journal of Strategic Property Management, 21(3), 240-255. https://doi.org/10.3846/1648715X.2016.1271369 